\title{
THE PARITY LAW IN PRACTICE: IMPLEMENTATION AND DIRECT OUTCOMES
}

\section{Ana Lúcia Teixeira*}

Ana Espírito-Santo

Maria Helena Santos

\begin{abstract}
Portugal adopted legislative quotas in 2006, passing the so-called Parity Law which specifies that candidate lists must include a minimum representation for each sex, and neither sex can occupy more than two consecutive positions in the candidate lists. This paper follows the Gender Equality Policy in Practice (GEPP) approach and aims to deepen our understanding of the adoption and implementation process of the Parity Law in Portugal. After mapping how the law was implemented in Portugal - including a description of the tools and instruments that were set up and how the process unfolded in practice - an assessment of the policy's direct effects is carried out, contributing to the open debate on the indicators of success related to legislative quota laws.
\end{abstract}

Keywords: Parity, law, women, equality, politics.

\section{Resumo}

A Lei da Paridade na prática: implementação e impacto direto

Portugal adotou em 2006 a Lei da Paridade, que assegura uma representação mínima de cada sexo, não podendo nenhum dos sexos ocupar mais de duas posições consecutivas

* Centro Interdisciplinar de Ciências Sociais (CICS.NOVA), Faculdade de Ciências Sociais e Humanas (NOVA FCSH), Lisboa, Portugal.

Postal address: CICS.NOVA, Colégio Almada Negreiros, Campus de Campolide, 1070-312 Lisboa, Portugal.

Electronic address: analuciateixeira@fcsh.unl.pt

** ISCTE - Instituto Universitário de Lisboa (ISCTE-IUL), Centro de Investigação e Estudos de Sociologia (CIES), Lisboa, Portugal.

Postal address: CIES-IUL, Av. das Forças Armadas, 1649-026 Lisboa, Portugal.

Electronic address: ana.espirito.santo@iscte-iul.pt

*** ISCTE - Instituto Universitário de Lisboa (ISCTE-IUL), Centro de Investigação e de Intervenção Social (CIS - IUL), Lisboa, Portugal.

Postal address: CIS - IUL, Av. das Forças Armadas, 1649-026 Lisboa, Portugal.

Electronic address: helena.santos@iscte-iul.pt

NB. The work of this author is funded by national funds through FCT - Fundação para a Ciência e a Tecnologia, I.P., under the Transitory Norm - DL 57 / 2016/CP 1359/CT0023. 
nas listas eleitorais. O artigo segue a abordagem Gender Equality Policy in Practice (GEPP) e visa aprofundar a compreensão do processo de adoção e implementação da Lei da Paridade em Portugal. Depois de mapear a forma como a lei foi implementada - incluindo uma descrição das ferramentas e instrumentos que foram criados e como se desenrolou na prática - é feita uma avaliação dos efeitos diretos da política, contribuindo para o debate sobre os indicadores de sucesso relacionados com as leis de quotas.

Palavras-chave: Paridade, lei, mulheres, igualdade, política.

\section{Résumé}

\section{La Loi sur la parité en pratique: mise en œuvre et impact direct}

En 2006, le Portugal a adopté la Loi sur la parité, qui garantit une représentation minimum de chaque sexe, ne pouvant aucun des sexes occuper plus de deux positions consécutives dans les listes électorales. Cet article suit l'approche de la Politique de L'égalité de Genre en Pratique (GEPP) et vise à approfondir la compréhension du processus d'adoption et de mise en œuvre de la Loi sur la parité au Portugal. Après avoir décrit la manière dont la loi a été mise en œuvre - y compris une description des outils et instruments crées et de la manière dont elle a été appliquée dans la pratique - une évaluation des effets directs de la politique est réalisée, contribuant pour le débat sur les indicateurs de succès liés aux lois sur les quotas.

Mots-clés: Parité, loi, femmes, égalité, politique.

\section{Introduction}

This paper presents an analysis of the implementation of the Parity Law, which was adopted in Portugal in 2006 (Organic Law 3/2006, 21 August). Up until 2019, according to this law, all candidate lists presented for legislative, European, and local elections were to include at least a 33\% minimum representation for each sex, and neither sex could occupy more than two consecutive positions. Parties that did not respect this threshold were fined. In 2019, this law was revised, and now $40 \%$ is the minimum percentage required for each sex; and whereas placement mandates remained unchanged, non-compliant party lists are currently rejected (Organic Law 1/2019, 29 March).

This analysis partially follows the Gender Equality Policy in Practice Project (GEPP) approach, as described by Engeli and Mazur (2018). This approach briefly addresses the adoption of the policy, and then focuses in-depth on the subsequent processes, particularly the implementation, the evaluation, and the direct impact of the policy. The main goal of this paper is therefore to systematise and discuss the implementation process of the Portuguese Parity Law, as well as its direct impact on gender balance in political representation.

For this purpose, the paper is structured as follows. The next section deals with the pre-adoption process, where the social and political context that led to the presentation of a quota law will be analysed; followed by a look into the decision-making process and a summary of the path that led to the approval 
of the law. In the fourth section, the instruments for the implementation are introduced. Here we analyse the different aspects of the institutional context that frame the implementation of the Parity Law. The fifth section is dedicated to the implementation itself, with a discussion of all the problems that concern the different actors involved. Finally, we address the direct impact of the law, specifically its influence on the descriptive representation of women in the three levels of government.

\section{The pre-adoption process}

Since the beginning of the democratic regime in Portugal (1974), there has been an ongoing concern about the political participation of women. In the first decades of democracy, that concern was mostly voiced by the most important women's policy agency - currently named the Commission for Citizenship and Gender Equality (CIG) - which was founded in 1975, and by the non-governmental organizations (NGOs) that started appearing in that period and that were supported by CIG in its NGO Section (Monteiro and Ferreira 2012). Representatives of women's departments of political parties used to have seats on the NGO Section of CIG, a factor which was probably decisive for those parties' position on women's representation. In fact, both the Portuguese Communist Party (PCP) and the Socialist Party (PS) made very brief references to the importance of defending the increasing participation of women in political and social life in their party manifestos for the 1979 election (in the case of PCP, p. 7) and for the 1980 and 1983 elections (in the case of PS, respectively p. 22 and p. 34).

However, we argue that the issue of women's political participation in decision-making did not really enter the Portuguese political agenda until the beginning of the 1990s. A more detailed analysis of the media agenda would have to be conducted, but we believe that there were two key moments in this time period. The first is the creation of a Working Group for Parity Democracy by the NGO Section of CIG in 1990. Its first initiative was to conduct an unprecedented public hearing with all political parties on 20 May 1991 - named "Political Participation and Parity Democracy' - right before the legislative election that took place on 6 October of the same year. The main goal was to gather inputs from party leaders on their willingness (or lack thereof) for a progressive achievement of parity (information kindly provided by Ana Coucello in 2017).

Another very symbolic moment took place on 31 January and 1 February 1994, when three female Portuguese MPs from different parties (Maria Belo, PS; Maria Santos, Os Verdes (The Greens); and Margarida Salema, Social Democratic Party - PSD) organized the "Parity Parliament" with Ana Coucello (Bettencourt and Silva Pereira 1995; Cabrera, Martins and Flores 2011). «For this initiative, 115 former and current female members of Parliament invited the same number of 
male partners to sit with them in a Parity Parliament gathered to debate the situation of women, citizenship, and parity democracy» (Espírito-Santo 2018, 218). The event not only had wide media coverage at the national level (Cabrera, Martins, and Flores 2011) but also received remarkable attention at the international level, patent in multiple academic references pointing to its innovative feature and striking symbolic impact (Hubert 2001; Woodward 2002; Norris and Krook 2011) and in its replication, por instance, in Ireland (Joint Committee on Justice, Equality Defence and Women's Rights 2009).

These advancements were clearly framed by the international context, namely by the Beijing Declaration and Platform for Action and the recommendations for a parity representation from the United Nations, the European Union and the Council of Europe (particularly its Recommendation No. 1269 of 1995) (Cabrera, Martins and Flores 2011; Monteiro 2011).

The issue, now clearly focused on the possibility of the adoption of a quota law, re-appeared on the political agenda at the end of the 1990s, when PS made its first attempt to introduce a gender quota law in 1998 (Baum and Espírito-Santo 2012). Notwithstanding the fact that this bill was rejected in parliament, it increased public exposure (Viegas and Faria 2001; Jimenez 2002; Meirinho Martins and Teixeira 2005; Dias 2011). Several NGOs and CIG were particularly active in 1999 and conducted many initiatives (see Espírito-Santo 2018 for some examples of those initiatives). Consequently, the percentage of women in parliament significantly increased in 1999.

It is important to add that, since 1988, PS has had internal quotas that require a minimum of $25 \%$ of each sex in both the national party organs and all multimember lists, although they were not fully implemented until 1999 (Baum and Espírito-Santo 2012). Also, in 1997, one year before PS introduced the first bill on gender quotas, the party negotiated with PSD and managed to revise the Portuguese Constitution (CPR) to guarantee that a future bill proposing a quota law would not be declared unconstitutional (Espírito-Santo 2018). Even if these two events demonstrate that PS was planning to implement a quota law at the national level for some years, the entrance of a left-wing party - the Left Bloc (BE), a party founded in 1999 that managed to get representation in parliament in the legislative election that took place in that same year (2/230 MPs) - as a strategic competitor of PS left-leaning voters (Baum and Espírito-Santo 2012; Weeks 2018) may have expedited the process. Four other bills were presented between 2000 and 2003 by both PS and BE. None of these bills was successful.

Among the political parties, only PS and BE pushed for the Parity Law in Portugal. The three remaining parties with parliamentary representation - PCP, PSD, and the right-wing conservative Christian Democrat Party (CDS-PP) opposed quotas for different reasons and have voted against all related bills. On the one hand, PCP considers social inequalities as the real problem, hence finding gender quotas a pyrrhic solution; on the other hand, PSD and CDS-PP emphasize 
merit as the means for candidate recruitment and do not recognize any gender discrimination along their parties' lines (even though some different stances can be found, especially in PSD). Within PS and BE, the roles of some key women have been considered decisive throughout the pre-adoption process (Baum and EspíritoSanto 2012; Espírito-Santo 2018) as they are often the ones who concern themselves with these issues and who attempt to resolve them.

\section{The decision-making process}

In 2006, one bill from PS - targeted at all three different types of elections (European, legislative, and local) - and three bills from BE - one on each type of election - were passed, on their general principles, in the Assembly of the Republic. These bills all proposed the adoption of a 33\% minimum representation for each sex.

Following the normal legislative process, these four bills were eventually merged into a single document and submitted to a final overall vote. With the favourable votes of PS and BE, the final text was approved and sent to the president of the Republic for enactment. The latter (Aníbal Cavaco Silva, affiliated with PSD) decided to veto the bill because he considered the sanctions - which in that first version implied the outright rejection of non-compliant party lists - excessive.

Consequently, the bill was sent back to the Assembly and amended. The former outright rejection for non-complying lists was substituted with fines on parties. The bill passed again, although this time only with the support of PS, which had the majority in Parliament. BE decided not to back the amended bill due to the less stringent sanctions.

Throughout the years, the way this matter was framed by political parties underwent some changes. During the 1990s, when the issue started entering the political agenda of PS, the chosen narrative was marked by expressions such as «positive discrimination of the least represented sex» and «equality of opportunities for citizens of either sex», signifying quotas emerged as the solution to an inequality observed in women's participation in political decision-making. Only from 2000 onwards, probably influenced by the approval of a parity law in France in 2000, did the narrative change to a parity conception of democracy. In fact, all bills that PS introduced from 2000 onwards and that BE ever proposed on this matter have the word «parity» in their titles and do not use the word «quotas» (Espírito-Santo 2018). Irrespective of this parity-focused narrative, both PS and BE have a soft conception of parity, that is, one that does not follow the more commonly used $50 / 50$ measure, using instead a quota of at least a third - or $40 \%$, since 2019 - for either sex. This soft operationalisation did not follow CIG's and several NGOs' preferences for true parity (50\%) (Monteiro 2011). 


\section{The instruments for implementation}

The success of public policy lies not only in its design but also in broader contextual factors that frame its implementation. Relying on the classification of instruments for policy implementation by Ingram and Schneider (1990), we will focus on the four main types of instruments to frame the implementation of the Parity Law in Portugal: the authority instruments, which impose regulatory constraints on behaviour, i.e., they authorise or ban particular behaviours; the incentive instruments, that provide encouragements, positive (rewards) or negative (sanctions), for target groups to adopt or change a particular behaviour; the capacity and learning instruments, which aim to inform and train the several actors involved; and the symbolic and hortatory instruments, which are mostly communication tools that enable exposing the positive and negative aspects and values linked to the targeted behaviour (Engeli and Mazur 2018, 115-116).

The Parity Law was enacted at a time when there were authority instruments in place in Portugal since it emerged within a favourable constitutional framework (see Espírito-Santo 2018). Since 1976, the CPR indeed contains the principle of equality (Art. 13), prohibiting formal discrimination based on «ancestry, sex, race, language, territory of origin, religion, political or ideological convictions, education, economic situation, or social condition», and since 1997 it has been included in the class of constitutions that contain affirmative action to promote the representation of women in politics (Miranda 1998). The article 109 of the CPR states that

the direct and active participation by men and women in political life is a condition and a fundamental instrument for consolidating the democratic system, and the law should promote equality in the exercise of civil and political rights and nondiscrimination on the basis of sex for access to political positions.

The Parity Law itself considers some incentive instruments that seek to achieve the law's goals by promoting encouraging behaviours. In the 2006 version of the law, for instance, if a candidate list did not comply, the respective party would be notified to correct the situation (Art.3). Failure to do so in due time had the following consequences (Art. 4): a) the public display of the list (outside the building of the respective district court); b) its dissemination through the website of the National Electoral Commission (CNE); and c) a reduction of public funding for electoral campaigns, depending on the degree of non-compliance (see Art. 7 for details). Regarding the current 2019 version of the law, if a candidate list does not comply, the respective party is notified to correct the situation (Art. 3), but failure to rectify the candidate list in due time now results in the rejection of the whole list (Art. 4).

In what concerns the capacity and learning instruments, "the tools that provide resources, knowledge and skills to catalyse and coordinate the actions of individual policy actors» (Engeli and Mazur 2018, 115), we find some effort among the 
political parties to promote gender equality in general and gender balance in political representation in particular, which include the organization of debates, conferences, demonstrations, and exhibitions ${ }^{1}$ to discuss and make visible the importance of a more equal participation and representation. Particularly PS and, to a lesser extent, PSD have specific training courses and capacity building initiatives, such as summer and winter schools ${ }^{2}$ and workshops ${ }^{3}$, in the case of PS, particularly through the National Department of Socialist Women; and PSD's Political Training Academy for Women. Parliament has also invested in several activities aimed at improving the debate and visibility of women in politics, such as the organization and hosting of conferences, debates, book launches, etc ${ }^{4}$. Additionally, CIG has been having a role in capacity building, putting into practice one of its main goals, which is to increase consciousness of both public opinion and political agents (Monteiro and Ferreira 2012). This includes, for instance, the translation, in 2009, of the training tool «Women Can Do It!» («Na política, as mulheres são capazes!», in the Portuguese title), originally published in 1992 by the Norwegian Labour Party Women in collaboration with AOF.

Regarding symbolic and hortatory instruments, we can highlight two awarenessraising campaigns that were launched in 2009, when the Parity Law was implemented for the first time in European, legislative, and local elections. One was promoted by the Portuguese government under the motto «Women make democracy better. Difference makes equality», and was aimed at divulging the law and emphasizing the benefits of a parity democracy; the other was a campaign developed by the Portuguese Platform for Women's Rights (a platform that congregates women's rights NGOs) entitled «50/50 - Women and Men in Political Participation», which was aimed at sensitising the population to the importance of gender-balanced political representation as a requisite for democracy ${ }^{5}$.

The Parity Law has, thus, benefited from a favourable context regarding the different types of instruments for its implementation.

1 Some of these initiatives can be found in the parties' websites or other online platforms: PSD: http: / / www.psdfamalicao.pt/_a_participacao_das_mulheres_na_politica_local_em_debate_ nas_quartas_na_sede; PCP: https://www.pcp.pt/tags/mulheres; CDS-PP: https://fb.me/e/ 1vhRQEpFD; PS: https://ps.pt/orgaos-do-partido-socialista/mulheres-socialistas-igualdadedireitos; BE: https://www.bloco.org/autarquias2/item/3239-propostas-e-pol\%C3\%ADticasmunicipais-\%C3\%A0-esquerda-igualdade-de-g\%C3\%A9nero.html [Accessed 28 June 2021]. E.g., https:/ / ps.pt/escola-de-verao-liderancas; https:/ / ps.pt/ universidade-de-verao-comecahoje; https://ps.pt/escola-de-inverno-do-dnms; https://ps.pt/mulheres-socialistas-organiza ram-escola-de-inverno-em-matosinhos [Accessed 28 June 2021].

$3 \quad$ E.g., https:/ / ps.pt/a-mulher-e-a-intervencao-no-espaco-publico; https: / / ps.pt / formacao-autar quica-planos-para-a-igualdade-no-poder-local [Accessed 28 June 2021].

$4 \quad$ E.g., Conference Women in Politics: Gender Policies and Visibility Strategies for Female Members of Parliament, in 2012; Equality Cafe: The Role of Women in Local Government, in 2017.

5 Both the capacity and learning instruments, as well as the symbolic and hortatory instruments, here reported consist of a sample of some examples. They are not the result of a systematic analysis. 


\section{The implementation itself}

The previously described story of the Parity Law in Portugal did not end at its approval. Political parties remain the central political actors on this matter since they are the main gatekeepers of the political system (Freire 2001; Kenny and Verge 2013). They are the ones responsible for the composition of the candidate lists and for accommodating the different interests involved.

Two strategies emerge from the implementation process which reveal only a moderate commitment with the law by most Portuguese political parties. The first one, which clearly aims to circumvent the law, constitutes an effort to comply with the law during an election only to go back to the old power structures after the ballots are counted. This happens when the candidate lists are set up according to the Parity Law rules but the winners resign from their positions and are replaced by the next candidates on the lists - this mainly happens with female winners and male substitutes. This strategy was particularly noticeable in local elections when the Parity Law was implemented for the first time, where this was done overtly in some cases (Santos and Amâncio 2012). However, this trend was not found at all in national elections (Espírito-Santo, Teixeira and Santos, forthcoming). This problem was targeted by the 2018 law revision proposal presented by the government, where «in the event of substitution of an elective mandate holder, under the terms of the applicable law, the mandate is given to a candidate of the same sex from the respective list» (Draft Law 117/XIII/3). This article was not approved.

The second strategy worth mentioning entails a tendency to comply only with the minimum requirements of the law in all elections up to the most recent one (2019) (Espírito-Santo, Teixeira and Santos, forthcoming), a propensity which had been noticed before (Teixeira 2016). Furthermore, the lower we move on the lists towards ineligible positions, the more common it is to find female candidates, revealing a still slight tendency for gendered allocation of places whenever legally possible (Espírito-Santo, Teixeira and Santos, forthcoming).

Based on interviews conducted with key actors from PS and PSD, other forms of resistances were revealed (Espírito-Santo, Teixeira and Santos, forthcoming). Although compliance with the Parity Law is never questioned, resistance towards it is still explicitly expressed by some members of PSD, who find it an exaggerated measure and worry about its supposedly missing meritocracy principle. In PS, instead, that discourse still emerges at the local but not at the national level. Another example of individual resistance, which is rather common at the local level in both parties, is the belief that there are often not enough available women candidates, particularly in rural and conservative areas (Espírito-Santo, Teixeira and Santos, forthcoming).

There are two last examples of passive institutional resistance which have helped weaken the policy's reach. According to the Parity Law, the candidate lists must guarantee a minimum representation of $40 \%$ for both men and women, and 
they must also follow a sequence rule: neither sex shall occupy more than two consecutive positions, in order to prevent women from being pushed to the bottom of the lists (hence, to ineligible positions). Although complying with the law should imply that these two rules are cumulatively followed, this has not been happening. Instead, just complying with the sequence rule has been considered good enough. Therefore, many candidate lists that comply with the sequence rule but not with the minimum threshold for either sex have been considered compliant anyway.

As mentioned earlier, the Parity Law of 2006 determined an assessment of its impact on the promotion of parity between men and women five years after approval, in 2011 (the period for assessment in the new version of the law is four years). In fact, a report was produced in $2011^{6}$, but it did not echo as expected. At the time, this academic work was not made public. Since then, only a brief report was produced on this matter (see Santos, Teixeira and Espírito-Santo 2018) ${ }^{7}$. This scarcity is detrimental to the implementation process, by hindering the evaluation's transparency and the commitment with gender transformation.

Considering all these deterrents, which indicate some latent resistance more than open opposition, the implementation process of the Parity Law reveals a compliance with the letter of the law but does not necessarily follow the spirit of the law.

\section{Assessing the direct impact on gender transformation}

The aim of this section is to assess the implementation of the Parity Law in its direct gender transformation outcome, i.e., the direct impact of the policy on the identified problem (Mazur 2017), which is, in this case, the underrepresentation of women in the different political elective instances. To do so, we address whether the implementation was successful in achieving the goals set by the Parity Law, i.e., its required minimum proportions (in other words, the letter of the law).

For this we will analyse a set of elections that include the pre-adoption and implementation of the Parity Law (original version of 2006 and revised version of 2019) stages, from 1999 to 2019, at different levels of government, namely seven legislative elections, five local elections, and five European elections. For this analysis, only the parties with parliamentary representation in this period will be considered ${ }^{8}$.

6 «Estudo sobre a aplicação da lei da paridade do projecto promoção da cidadania e da igualdade de género: relatório final», available at https: / / bit.ly/30A83rG [Accessed 20 May 2021].

7 The revised version of the law (29 March 2019) is more accurate on this: it specifically states the terms of the evaluation: every four years, CIG should produce an evaluation report on the impact of the law on the promotion of parity between men and women, including recommendations for improvement.

$8 \quad$ BE (Left Bloc), left-wing party; CDU (Unitary Democratic Coalition), left-wing coalition between the Portuguese Communist Party and the ecologist party Os Verdes (The Greens); PS (Socialist Party), centre-left party; PSD (Social Democratic Party), centre-right party; CDS-PP 
An analysis of the three levels of political power (European, national, and local), by political party, shows a clear effect of the implementation of the 2006 version of the Parity Law. In fact, in terms of the direct impact, the data shows that the minimum proportions required by the law $(33.3 \%)$ had been achieved when considering the candidate lists - where the law applies - for the two levels of government for which we can analyse candidates, namely European and national.

In the most recent European elections, held on 26 May 2019 and already under the revised version of the law, the percentages of female candidates presented by all candidate lists were particularly high. Hence, since 1999, as shown in Figure 1, the constitution of the candidate lists of all political parties reveals a clear success of the Parity Law. Consequently, since 2009 when, as previously mentioned, the Parity Law was implemented for the first time, the percentage of women elected to the European Parliament has increased at a much higher rate than the one registered in previous elections (see Figure 4).

\section{Figure 1}

Percentage of women candidates in European elections by political party (1999-2019)

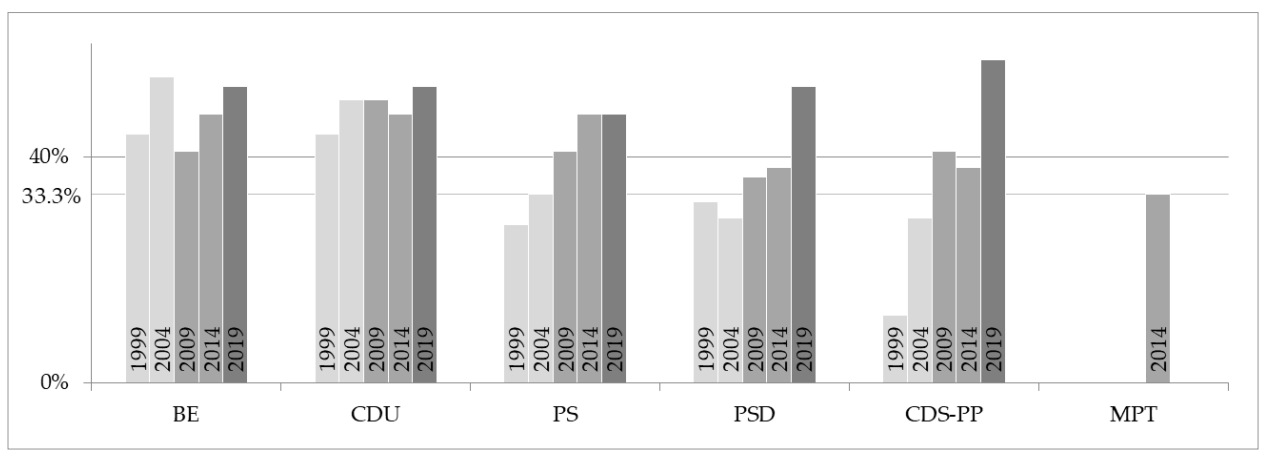

Note: In 2004 and 2014, PSD and CDS-PP ran as a coalition.

Source: SGMAI'.

With regard to national / legislative elections, the law also produced significant changes as early as 2009 (Figure 2). There was an increase in the percentage of women on all candidate lists, which was particularly visible among the political parties to the right of the political spectrum (PSD, 35.4\%, and CDS-PP, 38.0\%). In 2015, the recent People, Animals and Nature Party (PAN) stood out for the high

(People's Party), right-wing party; MPT (Earth Party), centre-right party founded in 1993; PAN (People, Animals and Nature), green party founded in 2009; LIVRE, left-wing party founded in 2014; IL (Liberal Initiative), liberal party founded in 2017; CHEGA, extreme right-wing party founded in 2019.

9 https:// www.sg.mai.gov.pt/AdministracaoEleitoral/EleicoesReferendos [Accessed 9 March 2021]. 
percentage of women on its lists (57.0\%); in 2019, PAN maintained its proportion of female candidates and three more parties achieved parliamentary representation: LIVRE presented a parity candidate list (50\%), Liberal Initiative (IL) presented $47.0 \%$ of female legislative candidates, and CHEGA presented $44.8 \%$ of female legislative candidates.

\section{Figure 2}

Percentage of women candidates in legislative elections by political party (1999-2019)

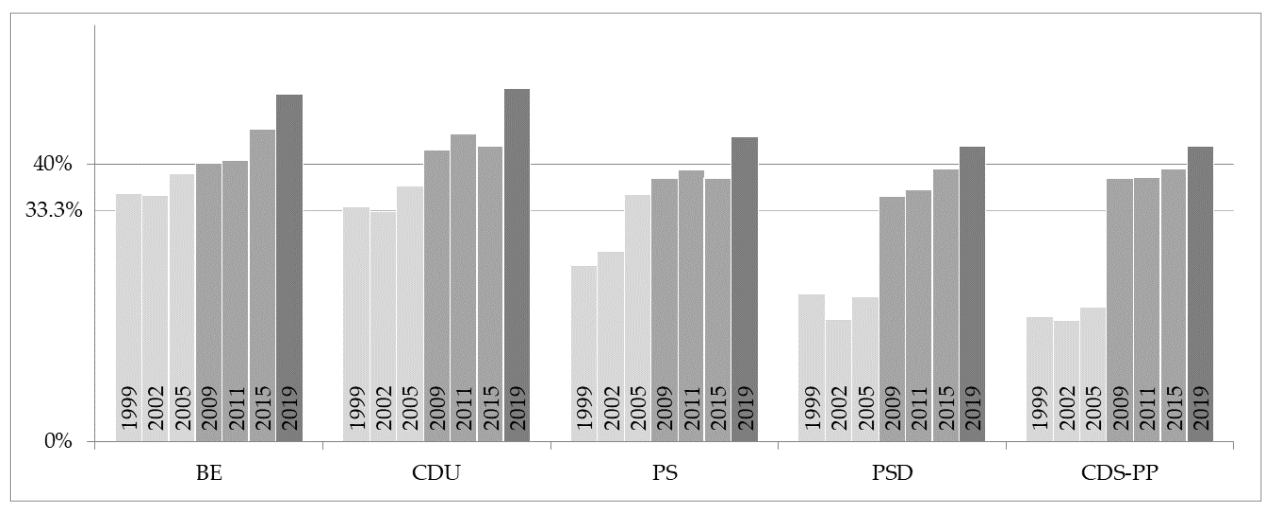

Note: In 2015, PSD and CDS-PP ran as a coalition.

Source: SGMAI ${ }^{10}$.

There is a clear increase in the percentage of women elected to Parliament as a consequence of the Parity Law (see Figure 4). Whereas in 2005 only $21.3 \%$ of women were elected to Parliament, in 2009 that percentage reached 27.8\%, and in 2019 it reached $38.7 \%{ }^{11}$.

Concerning local elections, we do not have data on the candidate lists, only on the elected representatives. However, we know that in every local election some candidate lists from several parties did not comply with the law, as made available by CNE on their website. Figure 3 presents the percentages of elected women in the four local political organs, the two deliberative organs (Municipal Assembly and Parish Assembly) and the two executive organs (City Council and Parish Council). It is clear that, in 2009, the implementation of the Parity Law boosted the proportion of elected women. However, the overall pattern remains:

https:/ / www.sg.mai.gov.pt/AdministracaoEleitoral/EleicoesReferendos [Accessed 15 March 2021]. In the 2011 election, there was a small decrease $(26.5 \%)$, which might be associated with the fact that Portugal was going through an economic and political crisis. It seems that, at that time, other concerns overcame parity, indicating that the Parity Law had not changed structural gender inequalities yet. 
low proportions of female incumbents (below the desired parity threshold, except for Municipal Assembly in $2017-34.6 \%$ ) and a lower relative presence of women in executive bodies, displaying the persistence of the association of men to decision-making and women to decision support, shown in previous studies (Lisboa et al. 2006).

\section{Figure 3}

Percentage of women elected in local elections by organ (2001-2017)

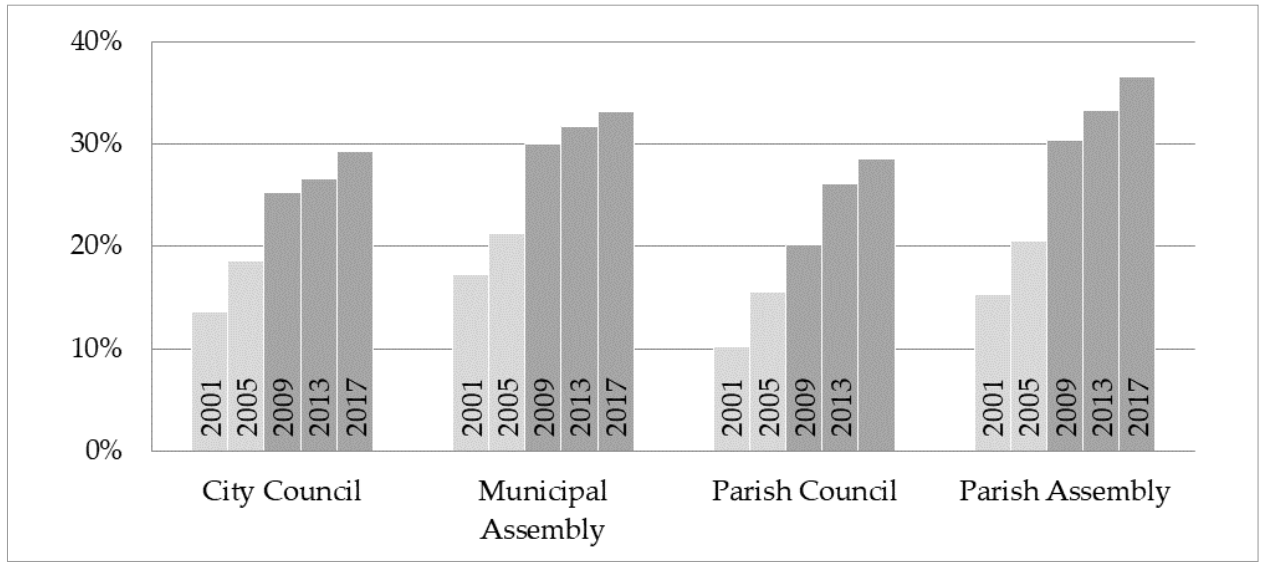

Source: SGMAI ${ }^{12}$.

Besides some cases of non-compliance with the law, namely in the local elections of 2009 to 2017, and some cases of strict compliance (for instance, the placement of women on the $3^{\text {rd }}, 6^{\text {th }}$ and $9^{\text {th }}$ positions), there is an overall compliance with the Parity Law, which resulted in a substantial increase of the proportion of elected women. Both versions of the law, in 2006 and in 2019, managed to boost previous results, as shown in Figure 4, revealing the direct gender transformation of all the elected levels of government, from a descriptive representation perspective.

However, in an analysis of the PS and PSD cases for the legislative elections (Espírito-Santo, Teixeira and Santos, forthcoming), we have found a consistently lower proportion of elected women than female candidates, hinting at a skin-deep commitment to the spirit of the law, which is to increase the share of women's political representation, while visibly complying with the letter of the law.

12 https://www.sg.mai.gov.pt/AdministracaoEleitoral/EleicoesReferendos [Accessed 15 March 2021]. Information provided by e-mail by SGMAI on 9 April 2021 regarding 2017 data. 
Figure 4

Percentage of elected women at all levels of government in Portugal, from 1999 to 2019

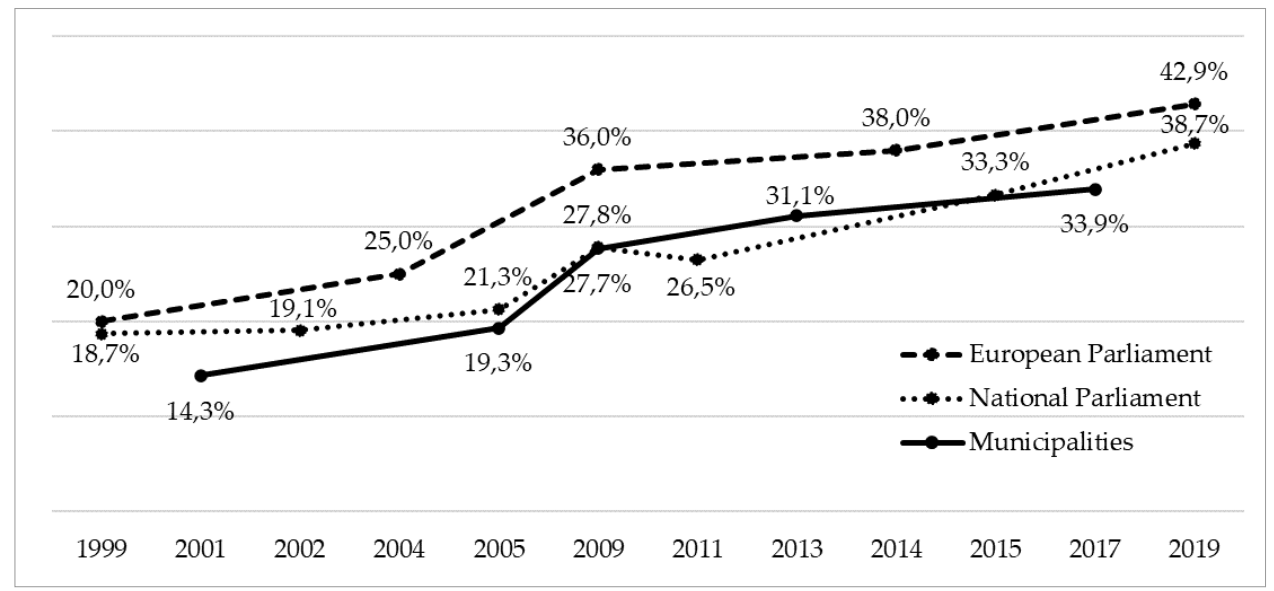

Source: SGMAI ${ }^{13}$.

\section{Conclusions}

Partially following the GEPP approach (Engeli and Mazur 2018), this paper focuses on the implementation and impact of the Parity Law adopted in Portugal in 2006 and revised in 2019. The main goal of the paper is to systematise and discuss the implementation process of the Parity Law as well as to identify to what extent this law has resulted in direct gender transformation, that is, a change in the descriptive representation of women in politics.

The Parity Law had a somewhat troubled history but found the support of both political and civil society stakeholders, although never with consensual status. At an early stage, work of internal (at Parliament level) sensitization had to be done, and the openness to this discussion surely benefited from international influences. But it was at the decision-making stage where resistance began to appear more clearly, revealing that the approved Parity Law was the attainable result of a negotiation process that ended in a script that fell short of the NGOs and the proposing parties' expectations, and resulted in a more soft approach to quota design (with a threshold of $33.3 \%$ and mild non-compliance sanctions).

Nevertheless, as we have argued, the institutional context for the implementation of the law was generally favourable in all the considered aspects (following

https: / / www.sg.mai.gov.pt/AdministracaoEleitoral/EleicoesReferendos [Accessed 9 and 15 March 2021]; regarding the 2017 local elections, information provided by e-mail by SGMAI on 9 April 2021. 
Ingram and Schneider's approach [1990]). Regarding the authority instruments, the CPR clearly states the participation by men and women in political life as a condition for consolidating the democratic system and is therefore considered to be in the class of constitutions that promote the representation of women in politics through affirmative action (Miranda 1998). Incentive instruments are also present, albeit in a negative way, in the form of non-compliance sanctions. To reinforce this feature, the 2019 revision of the Parity Law toughened sanctions. Capacity and learning instruments are also in place, with specific training and capacity-building actions being promoted by the two major political parties, along with a more broad set of activities aiming at the discussion and reflection on the importance of a gender-balanced political representation. Finally, also some symbolic actions were taken concerning sensitization to the importance of gender-balanced political representation. Consequently, the broader frame of the law's implementation can be considered positive.

It was with the implementation itself that the law faced more (covert) resistance. In fact, some practices were identified that circumvent the spirit of the law and hinder its effectiveness towards more thorough gender transformation. Despite the positive aspects of the interest shown by civil society and the action of national administrative bodies, such as CNE, some resistance was found among the main stakeholders of this process - the political parties -, revealing profound difficulties in challenging long-lasting power structures. Nevertheless, these seem to be dissipating and further studies should be conducted to analyse upcoming elections, to broaden the datasets on elections after the 2019 law revision.

In what concerns the general direct impact of the law in female political representation, the Parity Law can be considered a success, since it met its primary goal, which was to guarantee gender-balanced candidate lists. On a second level, the goal to consequently promote a balanced representation has generally been achieved, irrespective of the level of government considered: even though $40 \%$ of effective representation was only achieved among the European MPs (in 2019), the proportion of elected women has been consistently increasing and this growth has been more substantial since the Parity Law is in place.

Even though this was our goal, we have only discussed a part of the law's impact - the direct policy goals, i.e., descriptive representation. However, there are some signs that these transformations did not affect the more rooted gender asymmetries, since they did not eliminate most gender hierarchies that persist in the political world. In fact, the most powerful positions in Parliament and local governments are still overwhelmingly held by men. Furthermore, previous studies have shown a perception among female politicians that power is still in men's hands, and there is generalised consensus towards a soft approach to parity (Santos and Espírito-Santo 2017). Hence, notwithstanding great improvement, politics in Portugal still remains a gendered world. 


\section{References}

Baum, Michael, and Ana Espírito-Santo. 2012. «Portugal's 2006 Quota/Parity Law: An Analysis of its Adoption.» West European Politics 35(2): 319-342. DOI: https: / / doi.org / 10.1080/01402382.2011.648009

Bettencourt, Ana Maria, and Maria Margarida Pereira. 1995. Mulheres políticas: As suas causas. Lisboa: Quetzal Editores.

Cabrera, Ana, Carla Martins, and Teresa Mendes Flores. 2011. «Representações mediáticas das deputadas portuguesas: O "caso" do Parlamento Paritário.» Brazilian Journalism Research 7(11): 75-93. DOI: https: / / doi.org/10.25200/BJR.v7n2.2011.339

Dias, Nuno. 2011. «A paridade no Parlamento: itinerário de um paradigma.» Dinâmia Working Paper, 2011/20.

Engeli, Isabelle, and Amy Mazur. 2018. «Taking implementation seriously in assessing success: the politics of gender equality policy.» European Journal of Politics and Gender 1(12): 111-129. DOI: https: / / doi.org/10.1332/251510818X15282097548558

Espírito-Santo, Ana. 2018. «From Electoral to Corporate Board Quotas: The Case of Portugal» In Transforming Gender Citizenship. The Irresistible Rise of Gender Quotas in Europe, edited by Eléonore Lépinard and Ruth Rubio-Marín, 216-244. Cambridge: Cambridge University Press.

Espírito-Santo, Ana, Teixeira, Ana Lúcia, and Santos, Maria Helena. Forthcoming. «Implementing Gender Quotas in Portugal - A Success Story?» In Implementing Gender Quotas in Political Representation: Resisting Institutions, edited by Sabine Lang, Petra Meier, and Birgit Sauer. London: Palgrave.

Freire, André. 2001. «Sistema político, partidos e recrutamento parlamentar.» In Recrutamento parlamentar - Os deputados portugueses da Constituinte à VIII Legislatura, edited by André Freire, 23-53. Lisboa: STAPE.

Hubert, Agnès. 2001. «From Equal Pay to Parity Democracy: The Rocky Ride of Women's Policy in the European Union.» In Has Liberalism Failed Women? Assuring Equal Representation in Europe and the United States, edited by Jytte Klausen and Charles S. Maier, 143-163. New York: Palgrave.

Ingram, Helen, and Ann Schneider. 1990. «Improving Implementation by Framing Smarter Statutes.» Journal of Public Policy 10(1): 67-88. DOI: https: / / doi.org/10.1017 / S0143814 X00004682

Jiménez, Antonia María Ruiz. 2002. Mecanismos del cambio ideológico e introducción de políticas de género en partidos conservadores: el caso de AP-PP en España en perspectiva comparada. Madrid: Centro de Estudios Avanzados en Ciencias Sociales.

Joint Committee on Justice, Equality Defence and Women's Rights. 2009. Women's Participation in Politics. Second Report. Available at https://data.oireachtas.ie/ie/oireachtas/ committee/dail/32 / joint_committee_on_justice_and_equality / reports / 2009/200911-05_women-s-participation-in-politics_en.pdf

Kenny, Meryl, and Tania Verge. 2013. «Decentralization, Political Parties, and Women's Representation: Evidence from Spain and Britain.» Publius: The Journal of Federalism 43(1): 109-128. DOI: https:/ / doi.org/10.1093/publius/pjs023

Lisboa, Manuel, Graça Frias, Ana Roque, and Dalila Cerejo. 2006. «Participação das mulheres nas elites políticas e económicas no Portugal democrático (25 de Abril de 1974 a 2004).» Revista da Faculdade de Ciências Sociais e Humanas 18: 163-187.

Mazur, Amy. 2017. «Toward the Systematic Study of Feminist Policy in Practice: An Essential First Step.» Journal of Women, Politics E Policy 38(1): 64-83. DOI: http: / / dx.doi.org / 10.1080/1554477X.2016.1198210 
Meirinho Martins, Manuel, and Conceição Pequito Teixeira. 2005. O funcionamento dos partidos e a participação das mulheres na vida política e partidária. Lisboa: Comissão para a Igualdade e para os Direitos das Mulheres.

Miranda, Jorge. 1998. «Igualdade e participação política da mulher.» In Democracia com mais Cidadania: A questão da igualdade de participação política, edited by Vitorino Canas, Joana de Barros, Jorge Miranda, Leonor Beleza, Lúcia Amaral, Luísa Duarte, and Vital Moreira, 37-46. Lisboa: INCM.

Monteiro, Rosa. 2011. «A política de quotas em Portugal: O papel dos partidos políticos e do feminismo de Estado.» Revista Crítica de Ciências Sociais 92: 31-50. DOI: https: / doi. org $/ 10.4000 /$ rccs.3953

Monteiro, Rosa, and Virgínia Ferreira. 2012. «Metamorfoses das relações entre o Estado e os movimentos de mulheres em Portugal: Entre a institucionalização e a autonomia.» ex aequo 25: 13-27.

Norris, Pipa, and Mona Lena Krook. 2011. Gender Equality in Elected Office: A Six-Step Action Plan. Organization for Security and Co-operation in Europe. Available at https:/ / www. osce.org/odihr/78432

Santos, Maria Helena, and Lígia Amâncio. 2012. «Género e política: Análise sobre as resistências nos discursos e nas práticas sociais face à Lei da Paridade.» Sociologia, Problemas e Práticas 68: 79-101. DOI: https: / / doi.org/10.7458/SPP201268694

Santos, Maria Helena, Ana Lúcia Teixeira, and Ana Espírito-Santo. 2018. Balanço da implementação da Lei da Paridade em diferentes níveis de governo: Análise longitudinal. Lisboa: SECI /CIG. Available at https: / / www.cig.gov.pt/ 2018/03/ balanco-da-implementacaoda-lei-da-paridade-diferentes-niveis-governo-analise-longitudinal

Santos, Maria Helena, and Ana Espírito-Santo. 2017. «Para além dos números: Transformações de género associadas à Lei da Paridade.» Journal of Studies on Citizenship and Sustainability 2: 18-34.

Teixeira, Ana Lúcia. 2016. «Desigualdades de género nos cargos políticos em Portugal: Do poder central ao poder local.» PhD dissertation, Faculdade de Ciências Sociais e Humanas, Universidade Nova de Lisboa. Available at http:/ / hdl.handle.net/10362/ 20614.

Viegas, José Leite, and Sérgio Faria. 2001. As mulheres na política. Oeiras: Celta Editora.

Weeks, Ana Catalano. 2018. «Why Are Gender Quota Laws Adopted by Men? The Role of Inter- and Intraparty Competition.» Comparative Political Studies 51(14): 1935-1973. DOI: https: / / doi.org/10.1177/0010414018758762

Woodward, Alison. 2002. Going for Parity. Strasbourg: Council of Europe Publishing.

Ana Lúcia Teixeira. Has a PhD in Sociology and a master's degree in Data Prospecting and Analysis. She is an assistant professor at the Department of Sociology of the School of Social Sciences and Humanities, Universidade Nova de Lisboa (NOVA FCSH), and an integrated researcher at the Interdisciplinary Centre for Social Sciences (CICS.NOVA). Her research interests have focused on gender inequalities, in particular in the field of politics and violence against women, domestic violence and gender-based violence. 
Ana Espírito-Santo. Completed her $\mathrm{PhD}$ in Political and Social Sciences at the European University Institute (EUI), Florence, in 2011. Currently, she is an assistant professor at the Department of Political Science and Public Policies, ISCTE-IUL and a senior researcher at CIES-IUL (Lisbon, Portugal). Her main research interests are gender and politics, comparative politics and political representation. For more information see: http: / /www.anaespiritosanto.com/

Maria Helena Santos. Completed her PhD in Social and Organisational Psychology at the Instituto Universitário de Lisboa (ISCTE-IUL) in 2011. She is currently a researcher at CIS-IUL/ISCTE-IUL, Portugal. Her main research interests focus on gender studies and affirmative action in professional contexts that are markedly feminine and masculine, with a special emphasis on politics. She is the author and co-author of several books, chapters, and articles in national and international scientific journals.

Artigo recebido a 5 de julho e aceite para publicação em 14 de outubro de 2021. 